\title{
MANAGING CUSTOMERS: ANALYZING THE RELATIONSHIP BETWEEN CUSTOMER PERSONALITY, CUSTOMER SATISFACTION AND WILLINGNESS TO CREATE WOM
}

\author{
Adnan Butt ${ }^{1 *}$, Meer Suroor ${ }^{2}$, Salman Hameed $^{3}$, and Kashif Mehmood ${ }^{44}$
}

\begin{abstract}
The impact of personality traits on consumer behaviour is always an important concern for marketing researchers and practitioners. Using the theoretical lens of the OCEAN model this paper explores the personality attributes as a set of stimuli that facilitates consumer satisfactory buying experience, resulting in higher willingness to create Word of Mouth (WOM). The data was collected from consumers of different services through the convenience sampling method. The respondents were approached through different online platforms and data from 303 respondents was obtained through Google forms. 19 responses were found unsuitable for further use so the remaining 284 appropriate questionnaires were analyzed through structural equation modelling using AMOS23. The study findings suggest that willingness to create WOM has a positive relationship with customer satisfaction, while customer satisfaction can be driven by extraversion, conscientiousness, and agreeableness attributes of consumers' personalities. However, neuroticism and openness to experience showed an insignificant impact on customer satisfaction. The study findings guide marketing managers to consider the customer personality aspects mentioned in the OCEAN model to enhance customer satisfaction and try to obtain positive WOM from customers. This paper investigates the in-depth knowledge on the practicality of the OCEAN model concerning customer satisfaction coupled with customer willingness to create WOM.
\end{abstract}

Keywords: OCEAN Model; Willingness to create WOM; Customer Satisfaction, SEM Analysis, Service Industry; Word of Mouth.

\footnotetext{
${ }^{1}$ Sr. Assistant Professor, Bahria University, Pakistan; Email : adnanbutt.bukc@bahria.edu.pk

2 M.Phil. Scholar, Bahria University, Pakistan; Email: suroormeer@gmail.com

${ }^{3}$ Sr. Lecturer, Bahria University Pakistan; Email: Salmanhameed.bukc@bahria.edu.pk

${ }^{4}$ Sr. Assistant Professor, Bahria University, Pakistan; Email: kashifmehmood.bukc@bahria.edu.pk
} 


\section{INTRODUCTION}

The biggest challenge for the service industry players is that their offerings are intangible in nature and cannot be evaluated before consumers experience these services ( $\mathrm{Ng}$ et al., 2011). Buying a service seems to be riskier than any tangible product, so Dwivedi et al. (2021) suggested that the recommendation from service users are taken more truly by consumers. Literature indicates that consumers consider WOM as a more reliable medium than traditional media and almost $50 \%$ of consumers consider WOM as a critical factor for decision making in buying products/services (Dulek \& Aydin, 2020). Consumer pays more attention to other consumers' feedback rather than trusting the communication made by the service providers (Nieto et al., 2014). The significance of WOM on consumer purchase decisions and retention is well recognized by the industry.

A wide range of studies have been conducted to investigate factors that influence consumer willingness to create WOM and one of the most recognized factors is consumer satisfaction. According to Kalinic et al. (2020) and Yen and Wang (2020), consumer satisfaction is a vital contributing factor for willingness to create WOM. Service industries capitalize heavily in efforts to achieve consumer satisfaction that reinforces willingness to create WOM, resulting in the long term profitability of the industries (Cheng et al., 2021). Despite numerous research works the key drivers of consumers' satisfaction in the service industry are still need to be clarified. It becomes more important to understand these factors as dissatisfied consumers are probably having a negative influence on the industry's bottom line (Tajuddin \& Nayan, 2020). Thus, the path to consumers' willingness to create WOM does not begin with satisfaction, but rather with the drivers of satisfaction such as consumer's personality traits; a key driver of buying behaviour (Smith, 2020; Orji et al., 2017; Sofi \& Nika, 2016).

Although consumer characteristics have been used to predict consumer behaviour (Sofi \& Najar, 2018; Shahjehan \& Qureshi, 2019), but the focus of most studies was consumer demographics, while internal characteristics of personality have been overlooked in marketing researches. This study focuses on internal traits rather than consumer's demographics which are expected to evoke consumer needs and demands. Personality traits can affect consumer satisfaction levels (Smith, 2020; Ali, 2019), ultimately impacting consumers' willingness to create WOM. Lack of literature in developing countries like Pakistan, limits the marketers to fully understand the factors having an impact on consumer satisfaction and willingness to create WOM. 
This study is an attempt to fill the gap by proposing a conceptual framework focusing on consumers' personality traits explaining willingness to create WOM through consumer satisfaction. Therefore, this research shed light on consumer willingness to create WOM in service industries based on the OCEAN model (openness to experience, conscientiousness, extraversion, agreeableness and neuroticism) through customer satisfaction. The findings of this study would be contributing to the field of psychology and marketing, as it provides insight regarding the importance of consumers' big five personality traits on willingness to create WOM. The next section of the paper presents the literature review and conceptual framework proposed in this study. The third section presents the methodology adopted followed by statistical analysis. The paper then progresses through the discussion of the findings, implications, limitations and conclusion.

\section{LITERATURE REVIEW}

\section{Word of Mouth}

Word of mouth is considered one of the most effective tools in marketing affecting consumer behaviour (Daugherty \& Hoffman, 2014). Contemporary marketers give prime consideration to this marketing tool. Wangenheim (2005) defined WOM as person to person, noncommercial and informal communication between sender and receiver related to a product, business or service. Litvin et al. (2008) stressed on non-commercial aspect of WOM communication between the consumers of the product or service. The decision-making process of consumers is influenced by the information provided by these interpersonal exchanges through WOM, the effect of this information exchange surpasses the impact of formal advertising (Brown et al., 2007). Studies show that WOM is considered a more reliable medium by consumers. According to Katz and Lazarsfeld (1955), WOM is seven times more effective than newspaper and magazine advertising, four times more effective than personal selling and twice as radio advertising. WOM enhances the consumers buying intention by reducing the fear of trying out a new product (Olufemi \& Dastane, 2016).

Literature indicates that WOM is highly important in service marketing (Fisk et al., 2000; ZorBari-Nwitambu, 2017). Voyer and Ranaweera (2015) reported that in-service purchase decisions, WOM reduces consumers' level of perceived risk and uncertainty. The effectiveness of WOM is well accepted in different service industries; i.e., tourism (Albarq, 2014; Ali et al., 2019), restaurants (Muzamil et al., 2018; Jalilvand et al., 2017), health care (Martin, 2017; Chen et al., 2018), and higher education (Hsu, 2020; Chen, 2016). The difficulty in quality 
evaluation of service/service providers' makes consumers more relied on WOM to judge the reputation of firms (Bharadwaj et al., 1993). Due to technological advancement, a new form of electronic WOM is getting more prominence on digital platforms, influencing consumer behaviour rapidly (Yang, 2017; Gómez-Suárez et al., 2017).

\section{Factors influencing consumers' willingness to create WOM}

The existing literature suggests that several factors may have an impact on consumer's willingness to create WOM. According to Hajli et al. (2014) consumers, the purchase decision is very much influence by the trust in the service provider, inspiring them to create WOM. The brand commitment restricts the buyers from brand switching and initiating repeat purchases, enhancing the will to create WOM (Han \& Ryu, 2012). The social influence of WOM is also a significant factor to push customers to create WOM, as being a social phenomenon, reviews from customers are considered more dependable and reliable (Fang, 2014).

Price sensitive consumers were found to be more engaged in creating WOM, as they are inclined to obtain the best value for money by evaluating different alternatives (Kursan Milakovic \& Mihic, 2016). In high-risk buying scenarios, consumers are more dependent on WOM, so they are ultimately willing to create WOM for high perceived risk products (Alsulaiman et al., 2015). Demographic variables were also found to have an impact on willingness to create WOM; women are more interested to spread WOM than men (Loureiro \& Ribeiro, 2014), younger people are more involved in WOM seeking and spreading behaviour than older people (Schiffman et al., 2012). Customer satisfaction was recognized as a prime factor influencing customer's willingness to create WOM. According to Kalinic et al. (2020), satisfied customers are more willing to share their experience with others hence generating WOM.

\section{Consumer Satisfaction}

According to Putro et al. (2014), customer satisfaction is defined as an assessment of consumers' feelings and emotions for the use of products and services, where the performance meets the customers' expectations. Customer satisfaction can be a leading element of customer willingness to create WOM, as numerous empirical studies proved linkage among satisfaction, trust, commitment, and WOM (Back \& Lee, 2009; Ladhari 2007). The significant influence of WOM on consumers' purchasing behaviour is evident and most of the practitioners are inclined to include WOM in their marketing strategies (Kim et al., 2016). 
Consumer satisfaction is a prime antecedent of positive WOM (Liang \& Wang, 2007). Swan and Oliver (1989) said that satisfied customers are more often engaged in generating WOM than unsatisfied customers. Positive WOM created by customers have a positive impact on consumer preference, ultimately giving a good opportunity to the firms to increase their market share (Casalo et al., 2008). Strategically, WOM cannot be controlled by the firms and it is originated by the consumers themselves, thus directly related with the consumers' satisfaction to boost consumers' willingness to create WOM (Ranaweera \& Prabhu, 2003).

Hypothesis 1: Consumer satisfaction has a positive impact on consumer willingness to create word of mouth

\section{Personality Traits}

The prime objective of the marketers is to enhance and sustain customers' satisfaction but knowing the customers' response to the marketing efforts is key to attain this objective (Rexha, 2000). According to psychology, human behaviour can be studied through personality traits (Costa \& McCrae, 1992), which helps in understanding customers' responses to the marketing strategy. Personality is the reflection of stable and distinct thought patterns, behaviour and emotions to various life situations (Parks-Leduc et al., 2015). Different trait theories of personality have explained that what personality traits exist. In earlier theories, numerous possible traits were suggested, like Gordon Allport's list of 4,000 personality traits, Raymond Cattell's 16 personality factors, and Hans Eysenck's three-factor theory. The critic of Cattell's theory was its complexity and Eysenck's theory had very restricted scope. This resulted in the emergence of a well-acknowledged five-factor theory describing fundamental traits of personality.

The theory confirmation started to form the work of Fiske (1949) and was later extended by Norman (1967), Smith (1967), Goldberg (1981), and McCrae and Costa (1987). These five personality dimensions are Extroversion, emotional stability/neuroticism, agreeableness, conscientiousness, and openness to experience. Currently, most researchers believe that human personality is mainly dependent on these five core traits. In empirical studies by McCrae and Sutin (2018), Baumert et al. (2017) and Udo-Imeh (2015) it has been proved that human behaviour can be studied by a comprehensive taxonomy based on Big Five personality traits. 


\section{Openness to Experience (OTE)}

A person having a high score on the openness scale would be more creative, imaginative, analytical, curious, intellectual, open \& broad-minded (Weele, 2013). When compared with closed individuals, open individuals tend to experience more new things (Rossberger, 2014) and prefer to try more variety (Bozionelos et al., 2014). On the other hand, routine behaviour is followed by closed individuals (Turkyilmaz et al., 2015). In different researches, it was found that people showing high innovative and variety-seeking behaviour were early adopters of new products and services (Adjei \& Clark, 2010; Yeboah, 2018).

Openness to experience trait has a positive impact on job and career satisfaction (Mehrad et al., 2015), likewise, life satisfaction was also found to be dependent on this trait (Heidemeier \& Goritz, 2016). Life satisfaction and openness to experiences were found to have a positive significant relationship in students' life (Ali, 2019). In a study, Lin (2010) supported that openness personality trait had a positive impact on effective loyalty; an outcome of customer satisfaction. It can be inferred that the OTE trait may influence human satisfaction in different contexts including consumer buying.

Open individuals are willing to create WOM as this positively influences their selfenhancement. Also, individuals high on this trait experience more enjoyment through creating WOM (Guadagno et al., 2008; Almajali \& Bohari, 2016).

\section{Hypothesis 2: Openness to experience has a positive impact on consumer satisfaction.}

\section{Conscientiousness}

A conscientious person can be described as responsible, organized, trustworthy, selfdisciplined, punctual, thoughtful, and result oriented (Weele, 2013). People showing high on this trait are found to interact with others effectively (Ekinci \& Dawes, 2009) and are interested to have enduring relationships (Turkyilmaz et al., 2015). Conscientious people are advance planners and proactive (McCrae \& Costa, 2003), and aspire to be well informed (Mondak, 2010). Being constructive personality trait conscientiousness potentially has a positive impact on consumer buying practices. Customers having a high conscientiousness level show a better buying experience, leading towards a higher satisfaction level (Smith, 2020).

In a study related to the quality of relationships among co-workers, Organ and Lingl (1995) pointed out the negative relationship between conscientiousness and satisfaction. Conscientious leaders were found to be more rigid, resulting from low satisfaction of followers 
(Harris et al., 2019). Interestingly studies suggest that there is an adverse aspect of conscientiousness on human wellbeing, as more conscientious individuals were found to be less satisfied in their lives (Boyce et al., 2010). According to Yoo and Gretzel (2011), conscientious individuals are likely to create WOM after they have pondered on the potential outcomes of creating it. Conscientious people make themselves feel good by creating WOM, as it positively influences their self-enhancement as a motivation to create WOM.

Hypothesis 3: Conscientiousness has a positive impact on consumer satisfaction.

\section{Extraversion}

Extroverted individuals are very social, jovial, energetic, optimistic, dynamic, confident, talkative, bold, and dominant (McCrae \& Costa, 2003; Ekinci \& Dawes, 2009). Anyone scoring low on this scale would be more prudent, calm and avoid social interactions, while extroverted persons tend to have strong interpersonal relations (Mooradian \& Swan, 2006; Ekinci \& Dawes, 2009). Extrovert guests showed higher customer satisfaction in hotel service than the introvert guests (Jani \& Han, 2014), similarly, in the patients, it was found that extrovert patients expressed higher life and customer satisfaction (Proctor \& Best, 2019). In recent literature, it was stated that service professionals' job satisfaction was mainly determined by the extroversion dimension (Mróz \& Kaleta, 2016). According to Yoo and Gretzel (2011), extroverted individuals are motivated to create WOM as they gain energy from communicating in public.

Hypothesis 4: Extraversion has a positive impact on consumer satisfaction.

\section{Agreeableness}

Persons scoring better on this trait are sincere, compassionate, supportive, cooperative, and caring, while persons scoring lower on this trait are harsh, arrogant, stubborn, and irritable (Costa \& McCrae, 1992). Agreeable individuals tend to interact with others (Mondak, 2010) and these kinds of individuals are more inclined towards forming enhanced interpersonal relationships (Mooradian \& Swan, 2006; Barrick \& Mount, 1991). Moreover, these individuals believe that others are the best and are swiftly trustable (McCrae \& Costa, 2003). Dispute resolution and avoidance of clashes enforces them to neglect their value and needs (Olsen et al. 2016).

The aspect of satisfaction with life is influenced by the trait of agreeableness (Szczesniak et al., 2019). The study of Tan et al. (2004) provided the empirical evidence that demonstration of 
positive emotions is an indication of customer agreeableness which in turn enhances the satisfaction with service providers. According to the study of Matzler \& Renzl (2007) on utility companies, employee satisfaction is chiefly driven by the trait of agreeableness. Likewise, Jani and Han (2014) reported that guests scoring high on agreeableness trait were more often satisfied with the services in comparison with guests having low scores. Similarly, in the mobile phone services industry, the agreeableness personality trait was acknowledged as the distinct factor influencing customer satisfaction among the five core personality traits (Siddiqui, 2012). Individuals high on the agreeable trait have a high concern for others and this motivates them to create WOM, benefiting consumers and service providers Wang and colleagues (2012).

Hypothesis 5: Agreeableness has a positive impact on consumer satisfaction.

\section{Neuroticism}

An individual's desire to stay away from accountability in any situation comes under the definition of Neuroticism (Haq et al., 2010). These types of individuals are unstable, depressed, and anxious (Yoo \& Gretzel, 2011) and they show low trust levels coupled with more worrying behaviour (Freitag \& Bauer, 2016) leading to poor social relations (LePine \& Dyne, 2001). On the contrary, as per McCrae \& Costa (1987) people with emotional stability possess peaceful, forbearing, confident personalities with more social attributes.

It is generally considered that individuals with neuroticism are negatively prone to consumption behaviours (Jani \& Han, 2014; Volodina et al., 2019). Hlatywayo et al. (2013) have stated that negative relation exists between neuroticism and satisfaction, similarly, a study conducted in the context of banking services found that the trait of neuroticism indirectly influences customer satisfaction when mediated by negative affect (Ciunova-Shuleska \& Palamidovska-Sterjadovska, 2019). Moreover, the negative influence was exerted by the guests who were high pitched in neuroticism, leading to lower satisfaction with the services of the hotel industry (Jani \& Han, 2014).

Neurotic individuals consider that WOM is useless, enforcing them to restrict their feelings to create WOM (Correa et al., 2010). This trait also has a negative influence on concern for others so they are reluctant to help or warn other consumers (Yoo \& Gretzel, 2011).

Hypothesis 6: Neuroticism has a negative impact on consumer satisfaction. 


\section{CONCEPTUAL FRAMEWORK}

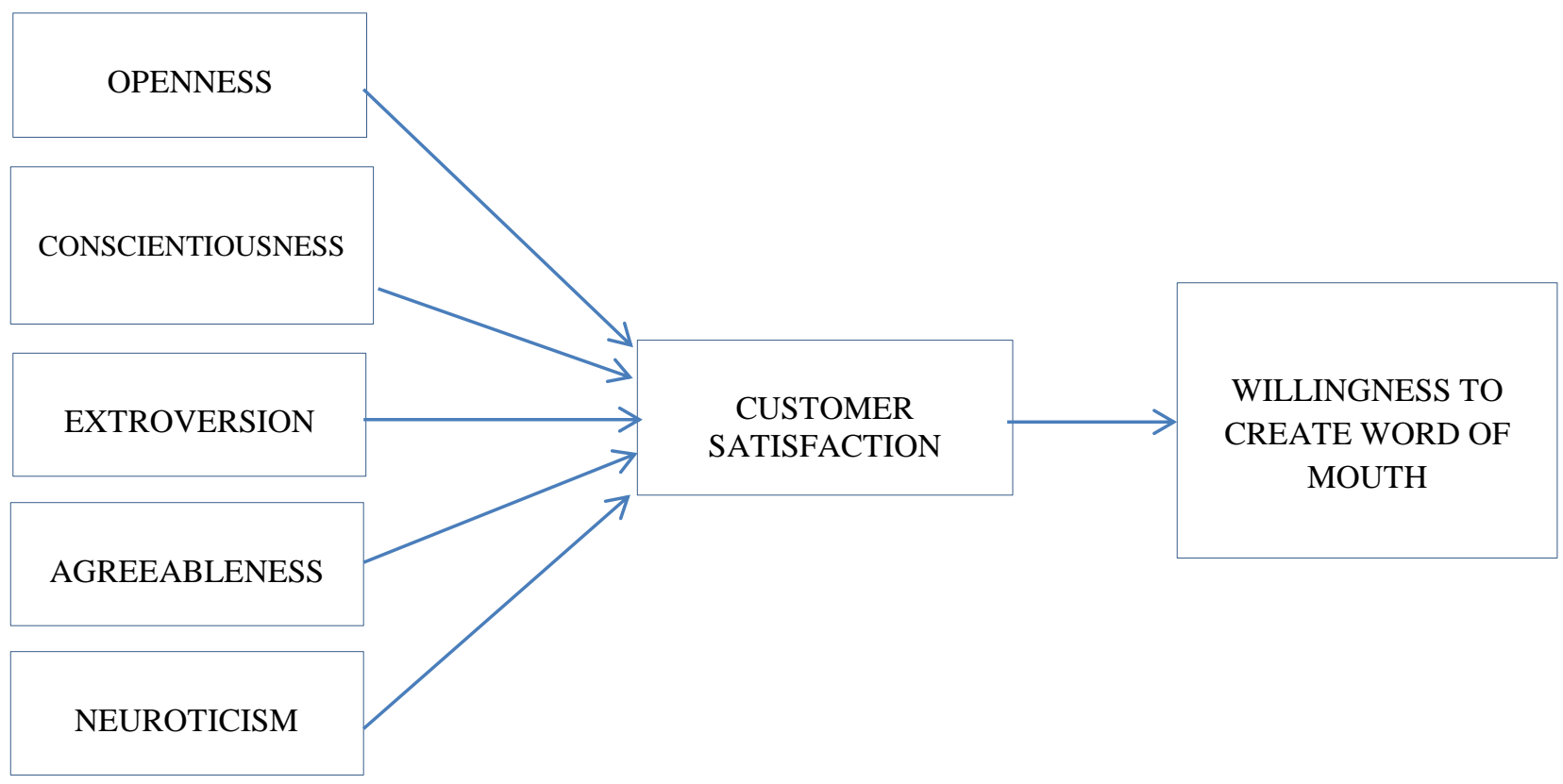

Source: Proposed model of the Study

\section{METHODOLOGY}

\section{Data and Sample}

Being a quantitative study, this research followed the deductive approach to examine the impact of personality traits on consumer satisfaction and willingness to create WOM. The data was collected from the consumers using services from banking, education, health, restaurants, and the telecommunication sector. The consumers who were easily approachable were contacted for data collection, so the method used for data collection was convenience sampling. The online version of the questionnaire was sent to the respondents through SMS, WhatsApp groups and social interactive websites. The respondents were given soft reminders wherever possible, in 47 days, 392 respondents answered the online questionnaire meeting the criteria of (Krejcie \& Morgan, 1970). By using the multivariate outlier technique, out of total responses 56 respondents were classified as outliers because of having an unusual combination of the values. After the exclusion of outliers, the final sample size of 336 was used for further analysis. Demographic questions were asked in the first part of the instrument regarding participants' gender, age, educational level and income group. The second part of the questionnaire comprised of items related to the variables in the research model. 
Table 1. Demographic Details

\begin{tabular}{|c|c|c|c|}
\hline & & Frequency (f) & Percentage $(\%)$ \\
\hline \multirow[t]{2}{*}{ Gender } & Male & 182 & 54.1 \\
\hline & Female & 154 & 45.9 \\
\hline \multirow[t]{6}{*}{ Age Groups (Years) } & Less than 18 & 2 & 0.5 \\
\hline & $18-25$ & 97 & 28.8 \\
\hline & $25-34$ & 153 & 45.6 \\
\hline & $34-44$ & 58 & 17.2 \\
\hline & $44-54$ & 17 & 5.0 \\
\hline & 54 above & 9 & 2.7 \\
\hline \multirow[t]{5}{*}{ Educational Level } & $\mathrm{PhD}$ & 8 & 2.38 \\
\hline & Masters & 146 & 43.4 \\
\hline & Bachelors & 151 & 45.0 \\
\hline & Intermediate & 17 & 5.0 \\
\hline & Matriculation & 14 & 4.1 \\
\hline \multirow{6}{*}{$\begin{array}{l}\text { Income Group } \\
\text { (Rs. In Thousands) }\end{array}$} & Less than 30,000 & 98 & 29.1 \\
\hline & $30,000-50,000$ & 65 & 19.3 \\
\hline & $50,001-70,000$ & 53 & 15.7 \\
\hline & $70,001-90,000$ & 35 & 10.4 \\
\hline & $90,001-110,000$ & 15 & 4.4 \\
\hline & More than 110,000 & 70 & 20.8 \\
\hline
\end{tabular}

Source: Data Analysis of this Study

In the survey response data, $54.1 \%$ of respondents were male, while $45.9 \%$ were female. Almost $75 \%$ of respondents were between 18 to 34 years old. More than $90 \%$ of respondents were having bachelors or master degrees. Almost half of the respondents were earning less than Rs. 50,000/month as mentioned in Table 1.

\section{Measures}

In this study, all the measurement instruments were taken from the previous literature with minor adaptations to fit in our study's context. Personality traits were described by the big five personality traits (OCEAN model). Personality traits were measured by using 44 items scale developed by John, Donahue and Kentle (1991) shown in Appendix A. Customer Satisfaction was measured by three items scale adapted from (Bitner, 1990). To measure willingness to create WOM five items scale was used, developed by Goyette et al. (2010). All the items were measured on a 5-point Likert scale ranging from 1 (Strongly Disagree) to 5 (Strongly Agree).

\section{Method of Analysis}

The data were analyzed in two steps as proposed by Anderson and Gerbing (1988). The reliability of the measurement constructs used in the study was confirmed by measuring 
discriminant and convergent validity. As recommended by Hair et al (2010) Structure Equation modelling was employed to test the hypotheses using Amos 21.

\section{RESULTS}

\section{Results of Measurement Model, Convergent Validity and Discriminant Validity}

Initially, the data was used to develop a CFA model to confirm the factor loading of all the constructs used in the study and check the model fitness. Different indices were used to check the model fit; the values are $\chi 2=470.66 ; \mathrm{df}=229 ; \mathrm{CMIN} / \mathrm{DF}=2.055 ; \mathrm{p}<.000 ; \mathrm{CFI}=.924$; TLI=.909; RMSEA=.056. According to Hu and Bentler (1999) criteria, all the values showed that model fit is good and well above the accepted values. All the items having factor loading less than 0.5 were removed to ensure the internal reliability of the indicators as indicated by Bagozzi \& Yi (1991).

Table 2. Factor Loadings of Constructs and Reliability Statistics

\begin{tabular}{|c|c|c|c|c|c|c|c|}
\hline Constructs & Indicator & $\mathbf{M}$ & SD & $\begin{array}{l}\text { Factor Loading } \\
0.5\end{array}$ & $\begin{array}{ll}> & \mathrm{CR} \\
& >0.7\end{array}$ & $\begin{array}{l}\alpha \\
>0.7\end{array}$ & $\begin{array}{r}\text { AVE } \\
>0.5\end{array}$ \\
\hline \multirow[t]{5}{*}{ WOM } & WOM1 & 3.60 & 1.08 & 0.632 & \multirow[t]{5}{*}{0.913} & \multirow[t]{5}{*}{0.882} & \multirow[t]{5}{*}{0.677} \\
\hline & WOM2 & 3.55 & 1.08 & 0.624 & & & \\
\hline & WOM3 & 3.37 & 1.12 & 0.643 & & & \\
\hline & WOM4 & 3.75 & 1.02 & 0.844 & & & \\
\hline & WOM5 & 3.60 & 1.13 & 0.871 & & & \\
\hline \multirow[t]{3}{*}{ CS } & CS1 & 3.75 & .960 & 0.807 & \multirow[t]{3}{*}{0.927} & \multirow[t]{3}{*}{0.879} & \multirow[t]{3}{*}{0.809} \\
\hline & $\mathrm{CS} 2$ & 3.73 & .960 & 0.885 & & & \\
\hline & CS3 & 3.76 & .968 & 0.829 & & & \\
\hline \multirow[t]{3}{*}{ EXT } & EXT3 & 3.93 & 1.02 & 0.743 & \multirow[t]{3}{*}{0.818} & \multirow[t]{3}{*}{0.741} & \multirow[t]{3}{*}{0.604} \\
\hline & EXT4 & 3.88 & 1.00 & 0.848 & & & \\
\hline & EXT8 & 3.63 & 1.17 & 0.606 & & & \\
\hline \multirow[t]{3}{*}{ AGR } & AGR2 & 4.13 & 1.04 & 0.586 & \multirow[t]{3}{*}{0.786} & \multirow[t]{3}{*}{0.632} & \multirow[t]{3}{*}{0.553} \\
\hline & AGR7 & 4.12 & .919 & 0.546 & & & \\
\hline & AGR9 & 4.30 & .858 & 0.598 & & & \\
\hline \multirow[t]{3}{*}{ COT } & COT6 & 3.95 & .918 & 0.520 & \multirow[t]{3}{*}{0.779} & \multirow[t]{3}{*}{0.712} & \multirow[t]{3}{*}{0.542} \\
\hline & COT7 & 4.09 & .866 & 0.672 & & & \\
\hline & COT8 & 3.80 & 1.01 & 0.517 & & & \\
\hline \multirow[t]{3}{*}{ NEUT } & NEUT2 & 2.67 & 1.30 & 0.611 & \multirow[t]{3}{*}{0.776} & \multirow[t]{3}{*}{0.735} & \multirow[t]{3}{*}{0.544} \\
\hline & NEUT5 & 2.60 & 1.18 & 0.536 & & & \\
\hline & NEUT7 & 2.45 & 1.14 & 0.670 & & & \\
\hline \multirow[t]{4}{*}{ OPEN } & OPEN1 & 3.90 & 1.05 & 0.663 & \multirow[t]{4}{*}{0.821} & \multirow[t]{4}{*}{0.714} & \multirow[t]{4}{*}{0.534} \\
\hline & OPEN4 & 4.02 & .965 & 0.610 & & & \\
\hline & OPEN5 & 3.54 & 1.04 & 0.603 & & & \\
\hline & OPEN8 & 3.82 & .925 & 0.660 & & & \\
\hline
\end{tabular}


The validity of the constructs was measured by composite reliability $(\mathrm{CR})$ and average variance extract (AVE) values. All CR coefficients were among 0.77 to 0.92 , exceeding the recommended cut off value of 0.7 (Hair et al., 2010). To evaluate the convergent validity of all latent constructs AVE values were calculated and all the values were found greater than the suggested cut-off value of 0.5 (Hair et al., 2010). Moreover, the overall reliability of the construct was confirmed through Cronbach's $\alpha$, where all the constructs except agreeableness exhibited coefficient value greater than 0.7 , showing an adequate level of reliability (Nunnally, 1978). All the results for CR, Cronbach's $\alpha$ and AVE are shown in Table 2.

After ascertaining internal consistency/reliability and convergent validity, the next step was to measure discriminant validity. The discriminant validity was measured by using Fornell and Larcker (1981) criterion. Correlation among the construct was less than the square root of Construct AVE value as shown in table 3, displaying high discriminant validity.

Table 3. Discriminant Validity: Fornell-Larcker Criterion

\begin{tabular}{|c|c|c|c|c|c|c|c|}
\hline Measure & AGRE & COT & CS & EXT & NEUT & OPEN & WOM \\
\hline AGRE & 0.708 & & & & & & \\
\hline COT & 0.314 & 0.924 & & & & & \\
\hline CS & 0.450 & 0.726 & 0.824 & & & & \\
\hline EXT & 0.439 & 0.358 & 0.364 & 0.571 & & & \\
\hline NEUT & -0.431 & -0.179 & -0.181 & -0.373 & 0.548 & & \\
\hline OPEN & 0.554 & 0.358 & 0.409 & 0.491 & -0.314 & 0.577 & \\
\hline WOM & 0.260 & 0.341 & 0.298 & 0.403 & -0.149 & 0.416 & 0.508 \\
\hline
\end{tabular}

Note: WOM=word of mouth, CS=customer satisfaction, EXT=extraversion, AGR=agreeableness, COT=conscientiousness, NEUT=neuroticism, OPEN=openness to experience

Source: Data Analysis of this Study

\section{Results of the structural model: Hypotheses Testing}

The next step is to test the hypotheses and examine the proposed causal relations among the constructs. The structural model was run on AMOS 21 and bootstrapping procedure with 2000 iterations was executed to enhance the statistical significance of sub-constructs and the path coefficients (Chin et al., 2008). In the study, six hypotheses were proposed. The results show that the first hypothesis, extraversion has a positive impact on consumer satisfaction has been accepted $(\beta=.168 ; \mathrm{p}<.05)$, consistent with previous studies results (Proctor \& Best, 2019; Mróz \& Kaleta, 2016). This shows that extrovert consumers would have higher consumer satisfaction and it concludes that as a marketer it's easy to satisfy extrovert consumers than introverts. It was found that the second hypothesis of the study stating that conscientiousness 
has a positive impact on consumer satisfaction has been accepted $(\beta=.288 ; \mathrm{p}<.05)$. Smith (2020) also found similar results, however contradictory results were reported by Harris et al. (2019). It affirms that consumers with high conscientious levels would show higher consumer satisfaction, supporting the fact that as a marketer it's easy to satisfy consumers who are high in conscientiousness level than consumers who are low in conscientiousness level.

The next hypothesis agreeableness has a positive impact on consumer satisfaction has been accepted $(\beta=.362 ; p<.05)$ validating the findings of Jani and Han (2014) and Siddiqui (2012). This shows that consumers showed higher consumer satisfaction due to the high agreeableness level. It justifies that as a marketer it's easy for a marketer to obtain customer satisfaction when they are targeting consumers exhibiting a high agreeableness level. The fourth hypothesis neuroticism has a negative impact on consumer satisfaction has been rejected $(\beta=.074 ; p>.05)$. The relationship between the variables was found insignificant so it can be concluded that the neuroticism level of the consumer has no significant impact on consumer satisfaction.

Table 4. SEM Estimations and Test of Hypothesis

\begin{tabular}{ccccccc}
\hline Hypothesis & Path & Estimate & S E & C R & P value & Result \\
\hline H1 & EXT $\longrightarrow$ CS & .168 & .055 & 3.035 & .002 & Supported \\
\hline H2 & COT $\longrightarrow$ CS & .288 & .092 & 3.126 & .002 & Supported \\
\hline H3 & AGR $\longrightarrow$ CS & .362 & .080 & 4.518 & $* * *$ & Supported \\
\hline H4 & NEUT $\longrightarrow$ CS & .074 & .072 & 1.026 & .305 & Not supported \\
\hline H5 & OPEN $\longrightarrow$ CS & .088 & .067 & 1.314 & .189 & Not supported \\
\hline H6 & CS $\longrightarrow$ WOM & .735 & .073 & 10.088 & $* * *$ & Supported
\end{tabular}

Notes: *Significant at the 0.05 level; ** Significant at the 0.01 level.

Source: Data Analysis of this Study

Although most of the studies including Volodina et al., (2019) stated that negative relation exists between neuroticism and satisfaction. It can be inferred that this personality dimension may not be taken into consideration while designing the marketing mix.

The fifth hypothesis openness has a positive impact on consumer satisfaction has been rejected $(\beta=.088 ; p>.05)$. The insignificant relationship reveals that openness to experience might not contribute to obtaining consumer satisfaction. The findings are contrary to Mehrad et al. (2015) and Castillo (2017) who found a positive impact between these variables. The last hypothesis stating that consumer satisfaction has a positive impact on willingness to create WOM has been accepted $(\beta=.735 ; \mathrm{p}<.05$ ). Prior study findings also support this result (Afridi et al., 2014; 
Taghizadeh et al., 2013). From this result, it can be concluded that satisfied customers would be more willing to create WOM than unsatisfied customers. This is an important finding for the marketers that if they want their customers to create positive WOM for their brand, they need to keep them satisfied.

Figure 1. Path Analysis

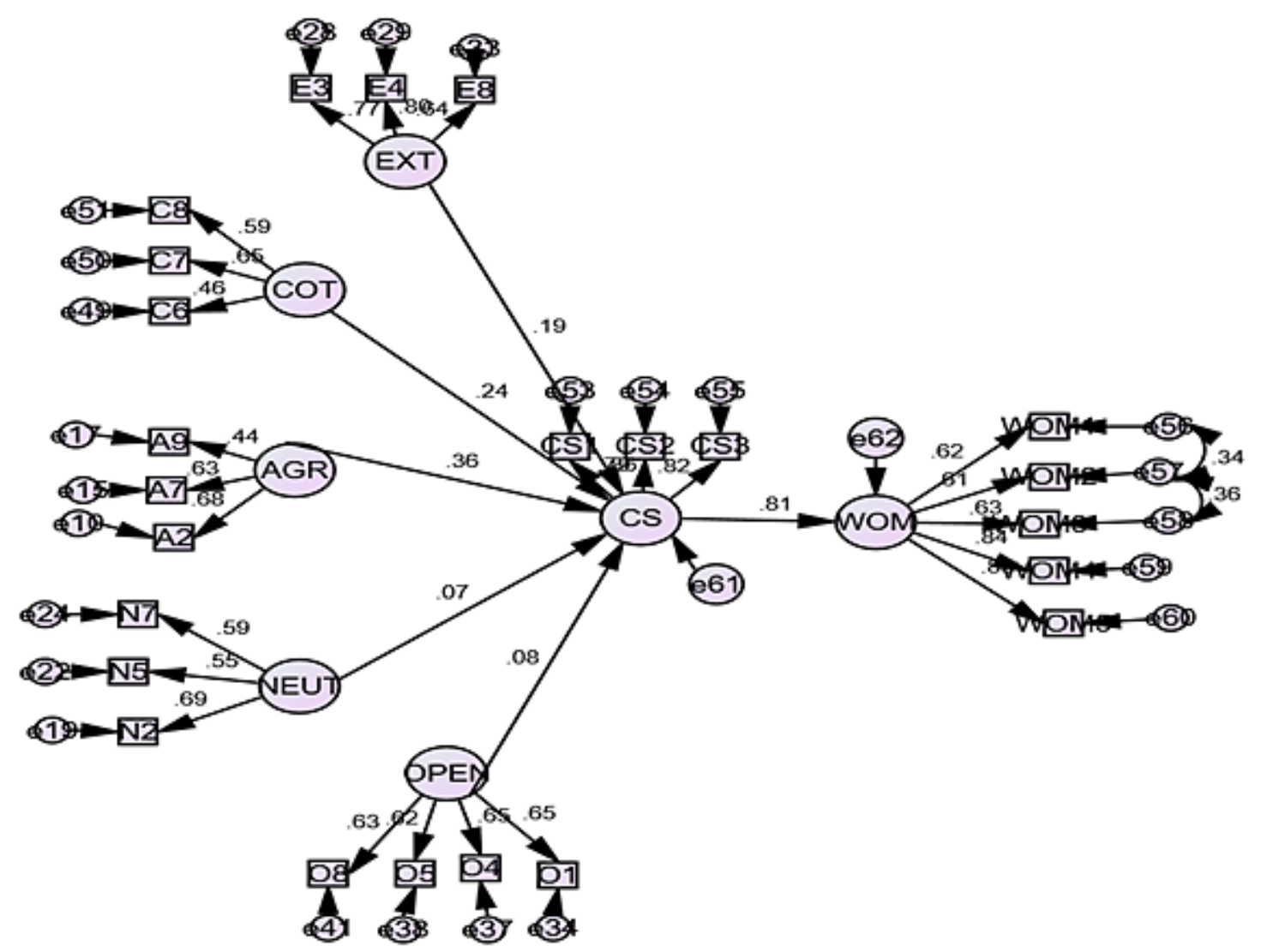

Source: Path Analysis

\section{CONCLUSION AND DISCUSSION}

Word of mouth (WOM) has already been recognized by marketers to be a highly credible form of marketing information. The impact generated by WOM has made it important for today's marketers to remain updated about its theory, power, effect and understanding. High involvement of today's consumers over the internet, WOM is gradually becoming a need for marketers and it has positioned itself as a topic which the marketers can't afford to ignore. It is of great importance particularly to the service industries where offerings are fundamentally intangible and require a personalized touch of customer service in order to generate positive reviews from the customers. In marketing, it is believed that a satisfied customer does the best 
advertising, who consciously and sometimes unconsciously becomes a campaigner and a firm's advocate, influencing the views and opinions of potential customers concerning the firm's offering.

In this study, it was focused that how one's personality has an impact on consumer's satisfaction and willingness to create word of mouth. The findings of the study concluded that not all aspects of personality influence consumer satisfaction. Extraversion, conscientiousness and agreeableness were found to have a positive impact on consumer satisfaction, while neuroticism and openness to experience were found insignificant. Extravert people are very social with confident personalities, having a positive attitude towards life, so it's easy to make them happy and satisfied than an introverted individuals. Their ability to communicate their needs and wishes effectively makes them more expressive than an introvert. Extroverts always gain energy talking in public, so while generating WOM they not only gain reputation and social benefits by engaging themselves in communicating with the public, but also get inner satisfaction.

Conscientious individuals are responsible, consistent, risks avoiders and create timely bonds that last for long and thus they refrain from complaining. These people when receiving consistent services are likely to create WOM. In comparison to less conscientious individuals, conscientious people are willing to create WOM because they comprehend that creating WOM will make them feel good about themselves. Agreeable individuals are more cooperative than less agreeable individuals. They seek cooperation as they are warm, considerate and more concerned with the well-being of others. Higher interpersonal harmony and a sense of belongings with the service provider(s) compel them to create WOM. Implicit higher concerns for others motivate them also to create WOM.

The findings suggested that openness to experience was found to have an insignificant impact on consumers' satisfaction because, in a society like Pakistan, people have a low tendency to experience new things. Common people don't switch brands regularly and tend to use similar products/services which they are using previously. Low-income level, lower motivation to explore novel things, and collectivist environment might be the most important factors behind this consumers' psyche. According to previous literature, neuroticism has a negative relationship with consumer satisfaction, but neuroticism was found to have no impact on consumers' satisfaction in this study. The far most reason behind this result might be the social structure of the society where conveying your negative expression are not taken very positively. 
Furthermore, the results revealed that consumer satisfaction has a positive impact on willingness to create WOM. This implies that if a consumer is satisfied with the services of the firm, this satisfaction level is communicated to their friends, relatives and colleagues. This WOM reassures other individuals to purchase products or services that are recommended by others. For service industry marketers knowing the importance of WOM is essential. They should adopt the practices to increase consumers' willingness to create WOM. The pleasant service encounter would lead to having a long-lasting relationship with the client, which eventually increases their willingness to recommend the service.

\section{FUTURE RECOMMENDATIONS}

This research comes with some limitations and subsequent opportunities for further study. Firstly, because of different social norms and the dependence of WOM on brand category/industry, the findings cannot be generalized to non-services industries. It is proposed that a similar study may be conducted in a different sector to validate the current findings.

In future studies, it may be investigated that how consumers involvement, expertise and demographic homophily have an impact on consumers' satisfaction and willingness to create WOM. Future research could similarly examine moderation effects on the relationship between key constructs and in particular WOM behaviour. The effect of customer demographics such as age, gender, income, frequency of contact, service type, and new versus experienced customers would be a worthwhile avenue for research. Additionally, the use of a self-reporting instrument to measure respondents' personalities might have involved inherent social desirability biases, self-distortion and other psychological barriers affecting the responses. Although the survey was anonymous, respondents may have scored themselves high on all dimensions conventionally perceived as desirable characteristics. Future researches could employ triangulation by asking significant others to report on an individual's behaviour along with self-report by respondents.

\section{RESEARCH IMPLICATIONS}

This study has several implications for the marketers of service industries. On the theoretical end, the findings of this study make a critical contribution to fill the gap in the literature of customers' willingness to create WOM. It provides a profound understanding of the role of personality traits in consumer satisfaction development. The study endorses that the dimensions of personality traits are a substantial factor and exert indirect influence on willingness to create WOM through consumer satisfaction. 
Marketers should not adopt the conventional consumer relationship management strategies to create WOM. Customer satisfaction cannot be obtained among customers uniformly; rather it depends on the personality traits of customers. This study can be detrimental for marketers to understand factors having an impact on consumers' willingness to create WOM, as this study acknowledges the significance of consumer satisfaction as a core consequence of personality traits. This understanding would help them to formulate and implement their marketing strategies and utilizes their limited marketing resources with maximum efficiency. It is suggested that service providing firms should focus more on the consumers with higher extraversion, conscientiousness and agreeableness traits while selecting the target market.

This finding may also help marketers in developing their advertising strategies. Blogs and discussions forums are the platforms to engage extrovert customers and to provide the opportunity to speak about the firm's products and services publicly, helping them to create WOM. According to psychology conscientiousness, people are more rational and have a higher need for information and updates, so when the marketers engage these consumers by sending brochures, product updates and service satisfaction forms. These consumers feel more satisfied and being a brand ambassador would be more likely to create WOM. Customers high on agreeableness can be targeted by using appropriate celebrities and co-branding activities.

\section{Author(s) Contribution:}

The first author contributed to the original conceptual framework and helped in the development of an original manuscript. The second and third authors contributed to data collection and revising the manuscript. Whereas, the fourth author contributed to the development of the discussion \& conclusion section and helped in finalizing the final manuscript. 


\section{REFERENCES}

Adjei, M. T., \& Clark, M. N. (2010). Relationship marketing in a B2C context: The moderating role of personality traits. Journal of Retailing and Consumer Services, 17(1), 73-79.

Afridi, S. A., \& Haider, M., \& Alam, W. (2014). Impact of Service Quality on Word of Mouth Communication; Mediating Role of Customers' Satisfaction. Journal of Managerial Sciences, 12(1), 1-10.

Albarq, A. N. (2014). Measuring the impacts of online word-of-mouth on tourists' attitude and intentions to visit Jordan: an empirical study. International Business Research, 7(1), $14-22$.

Ali, I. (2019). Personality traits, individual innovativeness and satisfaction with life. Journal of Innovation \& Knowledge, 4, 38-46.

Ali, M., Puah, C., Ayob, N., \& Raza, S. (2019). Factors influencing tourist's satisfaction, loyalty and word of mouth in selection of local foods in Pakistan. British Food Journal, $122,2021-2043$.

Almajali, W., \& Bohari, A. (2016). The Impact of Intrinsic Motivations on Electronic Word of Mouth Communication through Social Network Sites: Openness to Experience as a Moderator.

Alsulaiman, K., Forbes, S. L., Dean, D. L., \& Cohen, D. A. (2015). Relationships between perceived product values and three word of mouth variables. Journal of Customer Behaviour, 14(4), 277-294. https://doi.org/10.1362/147539215X14503490289260.

Anderson, J. C., \& Gerbing, D. W. (1988). Structural equation modeling in practice: A review and recommended two-step approach. Psychological Bulletin, 103(3), 411423. https://doi.org/10.1037/0033-2909.103.3.411

Back, K., \& Lee, J. (2009). Country club members' perceptions of value, image congruence, and switching costs: An exploratory study of country club members' loyalty. Journal of Hospitality and Tourism Research, 33(4), 528-46.

Bagozzi, R. P., \& Yi, Y. (1991). Multitrait-multimethod matrices in consumer research. Journal of Consumer Research, 17(4), 426439. https://doi.org/10.1086/208568

Barrick, M. R., \& Mount, M. K. (1991). The Big Five personality dimensions and job performance: A meta-analysis. Personnel Psychology, 44(1), 126. https://doi.org/10.1111/j.1744-6570.1991.tb00688.x

Baumert, A., Schmitt, M., Perugini, M., Johnson, W., Blum, G., Borkenau, P., ....Wrzus, C. (2017). Integrating personality structure, personality process, and personality development. European Journal of Personality, 31, 503-528. https://doi.org/10.1002/ per.2115.

Bharadwaj, S. G., Varadarajan, P. R. \& Fahy, J. (1993). Sustainable competitive advantage in service industries: A conceptual model and research propositions. Journal of Marketing, 47, 83-99. 
Bitner, M. J. (1990). Evaluating service encounters: The effects of physical surroundings and employee responses. Journal of Marketing, 54(2), 6982. https://doi.org/10.2307/1251871

Boyce, C., Wood, A., \& Brown, G. (2010). The dark side of conscientiousness: Conscientious people experience greater drops in life satisfaction following unemployment. Journal of Research in Personality, 44(4), 535-539.

Bozionelos, N., Bozionelos, G., Polychroniou, P., \& Kostopoulos, K. (2014). Mentoring receipt and personality: Evidence for non-linear relationships. Journal of Business Research, 67(2), 171-181.

Brown, J., Broderick, A. J., \& Lee, N. (2007). Word of mouth communication within online communities: conceptualizing the online social network. Journal of Interactive Marketing. 21, 2-20. Doi:10.1002/dir.20082.

Casalo, L. V., Flavián, C., \& Guinalíu, M. (2008). The role of satisfaction and website usability in developing customer loyalty and positive word-of mouth in the e-banking services. International Journal of Bank Marketing, 26(6), 399-417.

Castillo, J. (2017). The Relationship between Big Five Personality Traits, Customer Empowerment and Customer Satisfaction in the Retail Industry.

Chen, C. T. (2016). The Investigation on Brand Image of University Education and Students' Word-Of-Mouth Behaviour. Higher Education Studies, 6(4), 23-33.

Chen, M., Zhang, P., \& Chen, X. (2018). Influence of electronic and traditional word-of-mouth on patients' health-care-seeking behaviour. Social Behaviour and Personality: An international journal, 46(5), 759-768.

Cheng, G., Cherian, J., Sial, M. S., Mentel, G., Wan, P., Álvarez-Otero, S., \& Saleem, U. (2021). The Relationship between CSR Communication on Social Media, Purchase Intention, and E-WOM in the Banking Sector of an Emerging Economy. Journal of Theoretical and Applied Electronic Commerce Research, 16(4), 1025-1041.

Chin, W. W., Peterson, R. A. \& Brown, P. S. (2008). Structural equation modelling in marketing: Some practical reminders. Journal of Marketing Theory and Practice, 16(4), 287-98.

Ciunova-Shuleska, A., \& Palamidovska-Sterjadovska, N. (2019). Model of satisfaction involving affect and personality traits. Eurasian Business Review, 9(4), 485-500.

Correa, T., Hinsley, A. W., \& Gil, H. D. (2010). Who interacts on the Web? The intersection of users' personality and social media use. Computers in Human Behaviour, 26(2), 247253.

Costa, P. T., \& McCrae, R. R. (1992). The five-factor model of personality and its relevance to personality disorders. Journal of Personality Disorders, 6(4), 343359. https://doi.org/10.1521/pedi.1992.6.4.343 
Daugherty, T., \& Hoffman, E. (2014). eWOM and the importance of capturing consumer attention within social media. Journal of Marketing Communications, 20(1-2), 82102. Doi:10.1080/13527266.2013.797764.

DÜLEK, B., \& AYDIN, İ. (2020). Effect of Social Media Marketing on E-Wom, Brand Loyalty, and Purchase Intent. Bingöl Üniversitesi Sosyal Bilimler Enstitüsü Dergisi, (20), 271-288.

Dwivedi, Y. K., Ismagilova, E., Hughes, D. L., Carlson, J., Filieri, R., Jacobson, J., ... \& Wang, Y. (2021). Setting the future of digital and social media marketing research: Perspectives and research propositions. International Journal of Information Management, 59, 102168.

Ekinci, Y., \& Dawes, P. L. (2009). Consumer perceptions of frontline service employee personality traits, interaction quality, and consumer satisfaction. The Service Industries Journal, 29(4), 503-521. Doi: 10.1080/02642060802283113.

Fang, Y. H. (2014). Beyond the credibility of electronic word of mouth: Exploring eWOM adoption on social networking sites from affective and curiosity perspectives. International Journal of Electronic Commerce, 18(3), 67-101.

Fiske, D. W. (1949). Consistency of the factorial structures of personality ratings from different sources. The Journal of Abnormal and Social Psychology, 44(3), 329344. https://doi.org/10.1037/h0057198.

Fisk, R. P., Grove, S. J. \& John, J. (2000). Services Marketing Self-Portraits: Introspections, Reflections, and Glimpses from the Experts. Marketing Classics Press, Decatur, GA.

Fornell, C., \& Larcker, D. F. (1981). Evaluating structural equation models with unobservable variables and measurement error. Journal of Marketing Research, 18(1), 3950. https://doi.org/10.2307/3151312

Freitag, M. \& Bauer, P. C. (2016) Personality traits and the propensity to trust friends and strangers. The Social Science Journal, 53(4), 467-476. DOI: $10.1016 /$ j.soscij.2015.12.002

Goldberg, L. R. (1981). Language and individual differences: The search for universals in personality lexicons. In L. Wheeler (Ed.), Review of personality and social psychology, 2, 141-165. Beverly Hills, CA: Sage.

Gómez-Suárez, M., Martínez-Ruiz, M. P., \& Martínez-Caraballo, N. (2017). Consumer-Brand Relationships under the Marketing 3.0 Paradigm: A Literature Review. Frontiers in psychology, 8, 252. https://doi.org/10.3389/fpsyg.2017.00252.

Goyette, I., Ricard, L., Bergeron, J., Marticotte, F. (2010): e-WOM Scale: WOM measurement scale for e-services context, in: Canadian Journal of Administrative Sciences, Vol. 23, No. 1, pp. 5-23.

Guadagno, R. E., Okdie, B. M., \& Eno, C. A. (2008). Who blogs? Personality predictors of blogging. Computers in Human Behaviour, 24(5), 1993-2004. 
Hair, J. F., Black, W. C., Babin, B. J. \& Anderson, R. E. (2010). Multivariate Data Analysis, 7th ed., Prentice Hall, Englewood Cliffs, NJ.

Hajli, N., Lin, X., Featherman, M. S., \& Wang, Y. (2014). Social word of mouth: How trust develops in the market. International Journal of Market Research, 56(5), 673-689.

Han, H., \& Ryu, K. (2012). Key Factors Driving Customers' Word-of-Mouth Intentions in Full-Service Restaurants. Cornell Hospitality Quarterly, 53(2), 96-109. Doi: 10.1177/1938965511433599.

Harris, T. B., Cardador, M. T., Cole, M. S., Mistry, S., \& Kirkman, B. L. (2019). Are followers satisfied with conscientious leaders? The moderating influence of leader role authenticity. Journal of Organizational Behaviour, 40(4), 456471. https://doi.org/10.1002/job.2342.

Haq, I. U., Ramay, M. I., Rehman, M. A. \& Jam, F. A. (2010). Big Five Personality and Perceived Customer Relationship Management. Journal of Business \& Retail Management Research, 6(1), 37-45.

Heidemeier, H., \& Göritz, A. S. (2016). The Instrumental Role of Personality Traits: Using Mixture Structural Equation Modeling to Investigate Individual Differences in the Relationships between the Big Five Traits and Life Satisfaction. Journal of Happiness Studies, 17, 2595-612.

Hsu, C., Pan, Y., Yan, Q., \& Yan, M. (2020). Key factors influencing word-of-mouth intentions: the case of college freshmen in Taiwan. Measuring Business Excellence.

Hlatywayo, C., Mhlanga, T., \& Zingwe, T. (2013). Neuroticism as a Determinant of Job Satisfaction among Bank Employees. Mediterranean Journal of Social Sciences, 4, 549-554.

Hu, L. T., \& Bentler, P. M. (1999). Cutoff criteria for fit indexes in covariance structure analysis: Conventional criteria versus new alternatives. Structural Equation Modeling, 6(1), 1-55. https://doi.org/10.1080/10705519909540118

Jalilvand, M., Salimipour, S., Elyasi, M., \& Mohammadi, M. (2017). Factors influencing word of mouth behaviour in the restaurant industry. Marketing Intelligence \& Planning, 35, 81-110.

Jani, D., \& Han, H. (2014). Personality, satisfaction, image, ambience, and loyalty: Testing their relationships in the hotel industry. International Journal of Hospitality Management. 37, 11-20.

John, O. P., Donahue, E. M., \& Kentle, R. L. (1991). The Big Five Inventory-Versions 4a and 54. Berkeley, CA: University of California, Berkeley, Institute of Personality and Social Research.

Kalinić, Z., Marinković, V., Djordjevic, A., \& Liebana-Cabanillas, F. (2020). What drives customer satisfaction and word of mouth in mobile commerce services? A UTAUT2based analytical approach. Journal of Enterprise Information Management, 33(1), 7194. Doi: 10.1108/jeim-05-2019-0136. 
Katz, E. \& Lazarsfeld, P. F. (1955). Personal influence. Glencoe, IL: Free Press.

Kim, J., Naylor, G., Sivadas, E., \& Sugumaran, V. (2016). The unrealized value of incentivized eWOM. Marketing Letters, 27(03), 411-421.

Krejcie, R. V., \& Morgan, D. W. (1970). Determining sample size for research activities. Educational and psychological measurement, 30(3), 607-610.

Kursan Milakovic, I., \& Mihic, M. (2016). Predictors and effect of consumer price sensitivity: The case of Croatia. Forum on Economics and Business, 19, 3-26.

Ladhari, R. (2007). The Effect of Consumption Emotions on Satisfaction and Word-of-Mouth Communications. Psychology and Marketing. 24, 1085-1108.

LePine, J. A., \& Van Dyne, L. (2001). Voice and cooperative behaviour as contrasting forms of contextual performance: Evidence of differential relationships with Big Five Personality characteristics and cognitive ability. Journal of Applied Psychology, 86(2), 326-336. http://dx.doi.org/10.1037/0021-9010.86.2.326

Liang, C. J. \& Wang, W. H. (2007). An insight into the impact of a retailer's relationship efforts on customers' attitudes and behavioural intentions. International Journal of Bank Marketing, 25(5), 336-366.

Lin, L. Y. (2010). The relationship of consumer personality trait, brand personality and brand loyalty: An empirical study of toys and video games buyers. Journal of Product \& Brand Management, 19, 4-17. Doi: 10.1108/10610421011018347.

Litvin, S. W., Goldsmith, R. E., \& Pan, B. (2008). Electronic word-of-mouth in hospitality and tourism management. Tourism Management, 29(3), 458468. https://doi.org/10.1016/j.tourman.2007.05.011.

Loureiro, S. M. C., \& Ribeiro, L. (2014). Virtual atmosphere: The effect of pleasure, arousal, and delight on word-of-mouth. Journal of Promotion Management, 20(4), 452-469. https:// doi.org/10.1080/10496491.2014.930283

Martin, S. (2017). Word-of-mouth in the health care sector: a literature analysis of the current state of research and future perspectives. Int Rev Public Nonprofit Mark, 14, 35-56 https://doi.org/10.1007/s12208-016-0154-y.

Matzler, K., \& Renzl, B. (2007) Personality traits, Employee satisfaction and Affective Commitment. Total Quality Management, 18(5), 589-598. DOI: $10.1080 / 14783360601061528$

McCrae, R. R., \& Costa, P. X, Jr. (1987). Validation of the five-factor model of personality across instruments and observers. Journal of Personality and Social Psychology, 52, 81-90. https://doi.org/10.1037/0022-3514.52.1.81

McCrae, R. R., \& Costa, P. T. (2003). Personality in adulthood: A five-factor theory perspective. New York: Guilford Press 
McCrae, R. R., \& Sutin, A. R. (2018). A Five-Factor Theory Perspective on Causal Analysis. European journal of personality, 32(3), 151-166. https://doi.org/10.1002/per.2134.

Mehrad, A., Halimatussadiah, H., Redzuan, M., \& Abdullah, H. (2015). The Role of Personality Factors on Job Satisfaction among Academic Staff at Public Research University. Journal of Educational, Health and Community Psychology, 4, 2088-3129.

Mondak, J. J. (2010). Personality and the foundations of political behaviour. New York, USA: Cambridge University Press.

Mooradian, T. A., \& Swan, K. S. (2006). Personality-and-culture: The case of national extraversion and word-of-mouth. Journal of Business Research, 59(6), 778785. https://doi.org/10.1016/j.jbusres.2006.01.015.

Mróz, J., \& Kaleta, K. (2016). Relationships between personality, emotional labor, work engagement and job satisfaction in service professions. International Journal of Occupational Medicine and Environmental Health, 29(5), 767-782. https://doi.org/10.13075/ijomeh.1896.00578

Muzamil, M., Qadeer, A., Makhija, P., \& Jahanzeb, A. (2018). Impact of Different Factors in Creation of Word of Mouth at Hospitality Industry. Journal of Hotel \& Business Management, 7, 1-7.

Ng, S., David, M. E. \& Dagger, T. S. (2011). Generating positive word-of-mouth in the service experience, managing service quality: An International Journal, 21(2), 133-151.

Nieto, J., Hernández-Maestro, R. M., \& Muñoz-Gallego, P. A. (2014). Marketing decisions, customer reviews, and business performance: the use of the Toprural website by Spanish rural lodging establishments. Tour. Manage, 45, 115-123. Doi:10.1016/j.tourman.2014.03.009.

Norman, W. X (1967). 2800 personality trail descriptors: Normative operating characteristics for a university population. Ann Arbor: University of Michigan, Department of Psychology.

Nunnally, J. C. (1978). Psychometric theory (2 ${ }^{\text {nd }}$ ed.). New York: McGraw-Hill.

Olsen, S. O., Tudoran, A. A., Honkanen, P., \& Verplanken, B. (2016). Differences and similarities between impulse buying and variety seeking: A personality-based perspective. Psychology \& Marketing, 33, 36-47. https://doi.org/10.1002/mar.20853.

Olufemi, A. S. \& Dastane, O. (2016). The impact of word of mouth on customer perceived value for the Malaysian restaurant industry. The East Asian journal of business management, 6(3): 21-31.

Organ. D. W. \& Lingl, A. (1995). Personality, satisfaction, and organizational citizenship behaviour. The Journal of Social Psychology, 135(3), 339-350.

Orji, M. G., Sabo, B., Abubakar, M. Y., \& Usman, A. D. (2017). Impact of personality factors on consumer buying behaviour towards textile materials in South Eastern Nigeria. 
International Journal of Business and Economics Research, 6(1), 7-18. Doi:10.11648/j.ijber.20170601.12.

Parks-Leduc, L., Feldman, G., \& Bardi, A. (2015). Personality traits and personal values: A meta-analysis. Personality and Social Psychology Review, 19, 3-29. https://doi.org/10.1177/1088868314538548.

Proctor, C. J. \& Best, L. A. (2019), "Social and psychological influences on satisfaction with life after brain injury". Disability and Health Journal, 12(3), 387-393.

Putro, S. W., Semuel, H., Karina, R., \& Brahmana. (2014). Pengaruh Kualitas Layanan dan Kualitas Produk terhadap Kepuasan Pelanggan dan Loyalitas Konsumen Restoran Happy Garden Surabaya. Jurnal Manajemen Pemasaran, 2(1), 1-9.

Ranaweera, C. \& Prabhu, J. (2003). On the relative importance of customer satisfaction and trust as determinants of customer retention and positive word of mouth. Journal of Targeting, Measurement and Analysis for Marketing, 12, 82-90.

Rexha, N. (2000). Integrating Relationship Marketing Activities with Offering Quality in the Supplier's Relational Marketing Program. Journal of Business-to-Business Marketing, 26, 1-17. Doi:10.1300/J033v07n01_01.

Rossberger, R. J. (2014). National personality profiles and innovation: The role of cultural practices. Creativity and Innovation Management, 23(3), 331-348.

Schiffman, L. G., Kanuk, L. L., \& Hansen, H. (2012). Consumer behaviour: A European outlook, 2nd ed. Prentice Hall.

Shahjehan, A. \& Qureshi, J. A. (2019). Personality and impulsive buying behaviours. A necessary condition analysis. Economic Research-Ekonomska Istraživanja, 32(1), 1060-1072. Doi: 10.1080/1331677X.2019.1585268.

Siddiqui, K. (2012). Personality influences on customer satisfaction. African journal of business management, 6, 4134-4141.

Smith, G. M. (1967). Usefulness of peer ratings of personality in educational research. Educational and Psychological Measurement, 27, 967-984.

Smith, T. A. (2020). The role of customer personality in satisfaction, attitude-to-brand and loyalty in mobile services. Spanish Journal of Marketing - ESIC, 24(2), 155175. https://doi.org/10.1108/SJME-06-2019-0036.

Sofi, S. A., \& Nika, F. A. (2016). The role of personality in impulse buying behaviour. Jindal Journal of Business Research, 5(1), 2650. https://doi.org/10.1177/2278682116674079.

Sofi, S. A., \& Najar, S. A. (2018). Impact of personality influencers on psychological paradigms: An empirical-discourse of big five framework and impulsive buying behaviour. European Research on Management and Business Economics (ERMBE), Academia Europea de Dirección y Economía de la Empresa (AEDEM), 24(2), 71-81. 
Swan, J. L., \& Oliver, R. L. (1989). Post-purchase communications by consumers. Journal of Retailing, 65, 516-533.

Szcześniak, M., Sopińska, B., \& Kroplewski, Z. (2019). Big Five Personality Traits and Life Satisfaction: The Mediating Role of Religiosity. Religions, 10(7), 1-16.

Taghizadeh, H., Taghipourian, M., \& Khazaei, A. (2013). The Effect of Customer Satisfaction on Word of Mouth Communication. Research Journal of Applied Sciences, Engineering and Technology, 5, 2569-2575.

Tajuddin, W. N. S. W. A., \& Nayan, S. M. (2020). Rising customer satisfaction. Journal of Undergraduate Social Science and Technology, 2(2).

Tan, H. H., Foo, M. D., \& Kwek, M. H. (2004). The Effects of Customer Personality Traits on the Display of Positive Emotions. Academy of Management Journal, 47(2), 287296. https://doi.org/10.2307/20159579

Turkyilmaz, C. A., Erdem, S., \& Uslu, A. (2015). The effects of personality traits and website quality on online impulse buying. Procedia-Social and Behavioural Sciences, 175, 98105. doi:10.1016/j.sbspro.2015.01.1179

Udo-Imeh, P. T. (2015). Influence of Personality on the Buying Behaviour of Undergraduate Students in Universities in Cross River State, Nigeria. International Journal of Marketing Studies, 7, 64.

Volodina, A., Lindner, C. \& Retelsdorf, J. (2019), "Personality traits and basic psychological need satisfaction: their relationship to apprentices' life satisfaction and their satisfaction with vocational education and training”. International Journal of Educational Research, 93, 197-209.

Voyer, P. A., \& Ranaweera, C. (2015). The Impact of Word of Mouth on Service Purchase Decisions: Examining Risk and the Interaction of Tie Strength and Involvement. Journal of Service Theory and Practice, 25, 636-656.

Wangenheim, F. V. (2005). Post switching negative word of mouth. Journal of Service Research, 8(1), 67-78.

Wang, J. L., Jackson, L. A., Zhang, D. J., \& Su, Z.-Q. (2012). The relationships among the Big Five Personality factors, self-esteem, narcissism, and sensation-seeking to Chinese University students' uses of social networking sites (SNSs). Computers in Human Behaviour, 28(6), 2313-2319.

Weele, I. H. (2013). The effects of CEO's personality traits (Big 5) and a CEO's external network on innovation performance in SMEs.

Yang, F. X. (2017). Effects of restaurant satisfaction and knowledge sharing motivation on eWOM intentions: The moderating role of technology acceptance factors. Journal of Hospitality \& Tourism Research, 41(1), 93-127. Doi: 10.1177/1096348013515918.

Yeboah, A. (2018). An Exploration of New Product Physical Attributes and Consumer VarietySeeking In the Mobile Phone Category. 6. 1-14. 
Yen, T. F. T., \& Wang, M. H. (2020). Wine cultural event as a growing phenomenon: Role of novelty, value and satisfaction in developing WOM. Asian Journal of Education and Social Studies, 29-41.

Yoo, K. H., \& Gretzel, U. (2011). Influence of personality on travel-related consumer generated media creation. Computers in Human Behaviour, 27(2), 609-621.

ZorBari-Nwitambu, M. B. (2017). Positive Word of Mouth and Profitability: The Experience of Banks in Port Harcourt - Nigeria. International Journal of Managerial Studies and Research, 5(5), 42-48. 